\title{
A Descriptive Survey of Teachers' Perception of Triggers in Examination Malpractices: The Case of Public Examinations in Zambia
}

\author{
Banji Milumbe $\mathbb{D}^{D}$, Jackson Phiri $(\mathbb{D}$, and Mayumbo Nyirenda \\ Department of Computer Science, School of Natural Sciences, The University of Zambia, Lusaka, Zambia \\ Correspondence should be addressed to Banji Milumbe; banjimilumbe@gmail.com
}

Received 7 January 2021; Revised 28 September 2021; Accepted 28 December 2021; Published 24 January 2022

Academic Editor: Enrique Palou

Copyright (c) 2022 Banji Milumbe et al. This is an open access article distributed under the Creative Commons Attribution License, which permits unrestricted use, distribution, and reproduction in any medium, provided the original work is properly cited.

\begin{abstract}
Examination malpractices have continued to jeopardize the educational system despite several measures put in place to end the scourge. Perhaps the reason for this is that the root cause has not been thoroughly analyzed. This study has gone back to the root to find out the root cause of examination malpractices by getting the views of teachers on each stakeholder's acts of omission or commission that lead to examination malpractices. The stakeholders identified in this study are government, teachers, learners, and parents/community. A descriptive survey was adopted for this study. The population comprised all schools that conduct examinations offered by the Examinations Council of Zambia, while the target population was three (3) randomly selected schools per district with School Guidance Teachers purposively selected. A questionnaire was designed and administered to School Guidance Teachers. The obtained data were analyzed using descriptive statistics. The results revealed major contributing factors for each stakeholder, as for the learner factor being inadequate preparation for the examination, with the teacher factor being inadequate teaching and failure to complete the syllabus; poor and inadequate infrastructure was attributed to government, while, for the Parent/Community, it was lack of monitoring learners' school progress. The study recommends that, in order to nip examination malpractices in the bud, each stakeholder should play their honest part by negating the identified factors.
\end{abstract}

\section{Introduction}

The Examinations Council of Zambia (ECZ), created by an Act of Parliament Number 15 of 1983, chapter 137 [1,2], is mandated by law to conduct examinations and award certificates and diplomas to deserving candidates in Zambia. The increase in the number of candidates, examination centers, districts, and examination sessions offered by the ECZ has put a strain on the ECZ and Ministry of General Education in Zambia due to the increased risk of examination malpractices.

The school examination system in Zambia has been under threat due to examination malpractices that occur every examination session [3]. For several years, reports on examination misconducts have continued to occur as shown in Figure 1. Knowing the factors by each stakeholder that cause examination malpractices would help propose a practicable solution to condense examination malpractices in Zambia. Although a complete solution may not be found since as long as there are examinations, malpractices will always occur, but plummeting the vice to a minimum is possible. In order to reduce the vice and be able to detect the perpetrators when examination malpractice occurs, strict precautions are required.

Examination malpractices are a typical component in the Ministry of General Education ministerial statement every year when school examination results are released in Zambia. In the report by [4], it is stated that examination malpractices occur in both internal and external examination centers. It is a problem that has been afflicting the education system for many years not only in Zambia but worldwide. Different forms of examination malpractices happen every year such as of type "smuggling unauthorized materials into the examination room" where [4] indicated 


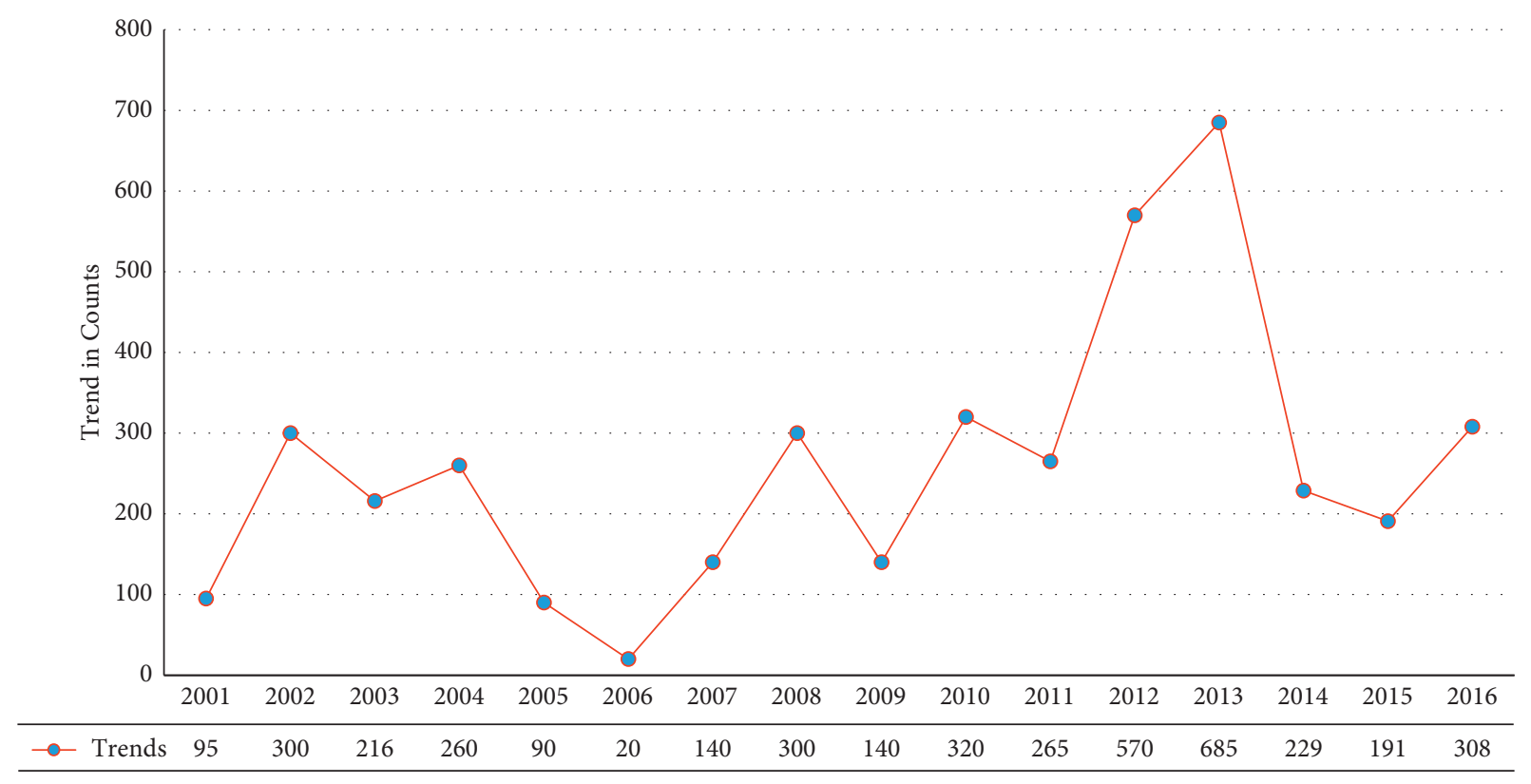

FIGURE 1: Reported trends in examination malpractices (2001-2016) [3].

that "such notes on small pieces of paper, exercise books, or transcribed answers in a coded form on pens, pencils, or rulers are meant to be used for writing the examination. Some candidates smuggle answers into the examination room by writing answers on the inner lining of their uniform shorts or shirts or dress collars, by writing answers or formulae on the soles of their shoes, writing on their body like palms or thighs" [4]. This is how deep this problem of examination misconduct is; perpetrators are determined to use whatever means they can think of to cheat in an examination.

In the 2013 examination session, the Joint SC (Grade 12) and GCE examination recorded cases of assistance as the most prevalent, followed by smuggling of unauthorized materials in the examination room [5]. Every examination season witnesses the emergence of new and inventive ways of cheating. Although measures to curb examination malpractices have been put in place, such as sensitization of stakeholders [5], examination malpractices still occur every year. Reports on theft of examination question papers and answer scripts from storage areas [6-8], candidates being assisted to write the examination, candidates having prior knowledge of the examination questions, submitting two scripts with two different handwritings and scripts of different subject papers written on different days being found in one packet, among others are some of the challenges that have continued to occur in the examination process [5] in Zambia. Measures put in place to reduce the menace have still not eradicated the problem. Knowing the key stakeholders and their roles in the examination management process and the factors that contribute to examination malpractices by each one of them would help in finding a lasting solution to mitigate the menace and focus the remedies on the right causes.

With the high value that has been placed on the School Certificate or Grade 12 Certificate in the Amended Zambia Constitution of 2016, which demands that anyone vying for political office must have a minimum of Grade 12 Certificate [9], the need to safeguard this qualification and ensure its credibility and international recognition has become even more important than before. It is therefore of paramount importance to carefully investigate the role of stakeholders in examination management that lead to cheating in an examination so that extenuating measures are put in place to address the problem.

An investigation on how each stakeholder contributes to examination malpractices would help come up with longlasting targeted solutions, which will address all loopholes that may lead to examination malpractices and leakages. Grouping the causes by each key stakeholder would help address the real problem as opposed to putting up general measures, which leave out certain receptacles in examination malpractices. A holistic approach is much more desirable now as examination malpractices are committed by various stakeholders and occur at different stages of the examination management process.

\section{Literature Review}

A wide range of literature has been reviewed, which encompassed the definition of examination malpractice, stakeholders in the examination management process, types 
of examination malpractices, effects of examination malpractices, and causes and possible solutions as proposed by other researchers.

2.1. Definition of Examination Malpractices. According to [10], an examination has been defined as "a formal test of a person's knowledge or proficiency in a subject or skill." The Collins dictionary gives this description of malpractice as "if you accuse someone of malpractice, you are accusing them of breaking the law or rules of their profession in order to gain some advantage for themselves" [11]. Every examination or assessment is governed by rules on how it should be conducted in order to make it fair to all those taking the assessment. These rules may come as instructions or guidelines on the examination timetable, question paper, in a handbook, or given orally as part of the assessment. Anything that would be done contrary to these guidelines constitutes examination malpractice. Combining the definitions of the two words, examination, and malpractice, we can simply put it that examination malpractice is breaking the law or rules pertaining to an examination, test, or an assessment to gain some advantage. Examination malpractices have been there for as long as there have been assessments or examinations. As assessment methods have evolved over time from traditional pen and paper to e-examinations, the situation has become more complex.

In describing the ugly face of examination malpractices, [12] referred it to as a cankerworm that is destroying the credibility of the examinations in Nigeria. This problem is not only in Nigeria, but a worldwide problem, because wherever there is an examination or assessment, the tendency to cheat is very high even from intelligent learners. In Zambia, the history of examination malpractice is not as clearly known but this vice has been there for a very long time. As far back as 20 years ago, we see that the vice has continued to haunt the examination system in Zambia.

Over the years, the definition of examination malpractice has remained the same with different scholars giving such definitions as "an improper and dishonest act associated with examinations with a view to obtaining unmerited advantage" [13], while [14] defines it as any act of omission or commission that contravenes the rules and regulations of the examination body to the extent of undermining the validity and reliability of the tests and ultimately, the integrity of the certificates issued", or simply "cheating in an examination [15]." The definition by [14] will form part of this study to find out the acts of omission or commission by different stakeholders in the examination management process that lead to examination malpractices. An examination or assessment is supposed to motivate a learner to study hard, so that they showcase their ability to retain what they learnt. This, however, is not usually the case in Zambia as most learners tend to resort to dishonesty practices when it comes to sitting an examination or writing any other assessment.

Examination malpractices are not limited to time and place of the examination as alluded to by [4], where these misconducts can occur before, during and after the examination. This entails that, at every stage of the examination management, there are stakeholders involved who could either be the same or different depending on the type of misconduct. For example, before the examination, a malpractice can occur if the persons given the responsibility to take care of the examination questions papers decide to expose the questions to unauthorized persons. Additionally, poor storage infrastructure can also contribute to leakages, because perpetrators would have easy access to the question papers. During the examination, learners can copy from each other or can be assisted by an invigilator or teacher, and after the examination, during marking, a marker can unilaterally allocate undeserved marks, or during processing, marks can be altered by staff of the examining body.

\subsection{Stakeholders in the Examination Management Process.} According to the literature that was reviewed, a wide range of stakeholders have been identified as critical in the examination management process. Among some of the identified stakeholders involved in the examination management process are teachers, pupils, parents, the community, government, and invigilators. The tendency to cheat in an examination is not only by learners as [16] rightly noted that examination malpractices "may be committed by not only the candidates, but also other bodies charged with the responsibilities of examination management." Each of these stakeholders has a role to play in the examination management process. For example, a learner is there to learn and then takes the assessment, parents provide support to learners during the course of their learning, and teachers teach learners according to the prescribed syllabus, while the government provides a conducive environment for examinations, teaching, and learning by providing educational materials and good infrastructure. Any act of omission or commission by any of the stakeholders involved can lead to "breaking the laws" regarding assessments or examinations. This study used stakeholder's model in which certain stakeholder actions were explored that are linked to the causes of examination malpractices. This model is described in more detail in the conceptual model section.

2.3. Forms of Examination Malpractices. Examination malpractices take different forms, which are associated to different stakeholders. Some of the forms of examination malpractices noted in the Zambian examination system include impersonation, leakages, copying and collusion, smuggling of written answers or notes, and external assistance. Similar forms have also been identified by other researchers [17-20], who, in addition, identified postexamination malpractices that are traceable to the staff of the public examination boards and the examiners who mark the candidate's scripts. Although different scholars have stated different forms of cheating, new forms have emerged with the advancements in technology.

As technology advances and changes emerge in how assessments are conducted, cheating also takes another level and form to match up with the method of assessment. For instance, e-learning and e-assessment have their own challenges, and 
systems and/or ways of detecting cheating in such environments are being implemented. To mitigate the unique exam security threats that exist in m-learning environments like impersonation, [21] in a paper entitled "Designing a Secure Exam Management System (SEMS) for M-Learning Environments" proposed the design of a secure examination management system. The study focused on securing e-examinations and detecting cheating with little information on the causes of cheating in an examination.

The different forms of cheating identified require attention so as to identify the stakeholders behind each form, and straight solutions pertaining to each stakeholder are applied. These studies did not put much effort in identifying and grouping the forms according to each stakeholder of which this study aimed at doing. The author [16] noted "other bodies" involved in examination malpractices but did not clearly state who these "other bodies" are. It is clear that there are various stakeholders involved in examination misconducts whom this study endeavored to identify together with their roles.

2.4. Effects of Examination Malpractices. A review of the past 20 years in Zambia shows that examination malpractices have been there in each examination session whether in certain years there have been some reductions or increases, and the fact still remains that this vice has continued to threaten the whole education system. Not everyone involved in this bad practice is caught, and others get away with it and continue to cheat their way through their education and even in their work life. This is confirmed by empirical evidence of [22] who postulates that "students who bribe their ways out of the exam halls will only go ahead to make the community in which they find themselves more corrupt." With this, the need to know and stop this vice is very important.

Examination malpractices tend to contradict highly with any government's intention to provide its citizens with the quality education necessary for the positive development. Its effects have a far-reaching consequence, which haunts society for a lifetime. A posting that once circulated on social media described the effects of examination malpractices whereby a Pharmacist and Nurse gave and administered drugs to a patient who eventually died due to wrong medication. The son of the patient who died requested to see the Pharmacist and Nurse who were responsible for the death of his mother. Upon seeing the two, he recognized them as the two girls he had assisted in an examination some years back. At that moment, he just exclaimed "I killed my mother several years ago." This is how far reaching the effects of examination malpractices can go and hence the need to critically address this matter.

2.5. Causes of Examination Malpractices. The causes of examination malpractices have been investigated by many scholars especially in West African Countries like Nigeria and Ghana. Although in Zambia some studies have been conducted on the subject of examination malpractices, there appears to be a dearth of research on the role stakeholders play that contribute to examination malpractices. Other authors like [17] focused on the effects on a particular group of learners in a specific subject. A countrywide survey, which could give views from all parts of the country, has never been conducted in Zambia. And this study endeavored to include all the provinces and districts in the country. Most of the causes found out by other scholars were lack of guidance and counselling services in schools, dwindling/falling standards of Education [19], and pupils not adequately preparing for examinations [20]. In Zambia, in order to provide guidance and counselling services in schools, the Ministry of General Education has established a Guidance and Counselling section in every school. Perhaps the question may be how effective this service/section is in helping learners, so that they do not involve themselves in examination malpractices. Since the guidance and counselling section's focus in the school is on learners, other stakeholders like the teachers do not seem to have this facility in the school as stakeholders in the examination management process.

Investigations in examination malpractices have not just been limited to secondary schools but even at tertiary level, dishonesty in examinations in common. The author [23] among other factors found that academic cheating is related to students' identity and their sensitivity to social evaluation. On the other hand, in analyzing the management of examination malpractices at colleges of education, [24] revealed other factors that cause examination malpractices such as emphasis on the certificate obtained, poor examination paper setting, and low salary level of personnel that handle examinations. Although other causes such as inadequate facilities, inadequate trained teachers, moral decadence, and external interference were cited, there is no clear indication as to which stakeholder they relate to. In this study, we felt that apportioning each factor to a particular stakeholder in the examination management process would help find solutions in eradicating this menace. Furthermore, indiscipline among students, nonimplementation of the examination malpractice decree, and lack of effective supervision during examinations were identified by [25-27]. In all these identified causes, there is no clear distinction probably just implied as to who is responsible for each of these factors. In addition, weak strategies to curb examination malpractices employed in some institutions were cited as a reason for continued misconduct in examinations [24]. Perhaps these weak strategies are as a result of missing the target by not focusing the remedial strategies on stakeholders involved in the menace. We thought that identifying the factors by stakeholder would help strengthen the strategies and come up with targeted solutions to the problem of examination malpractices in Zambia, which can also be applied anywhere else.

Ranking examination results in Zambia by School, district, and province was also perceived to be a contributing factor to examination malpractices, because each entity wanted to be at the top list. As a result, the Ministry of General Education removed school and district rankings from the results analysis in order to curb examination malpractices. This factor could perhaps be authenticated further by the findings of the research undertaken thus far, which indicate that 
students' participation in acts of examination malpractice was as a result of school performance rankings [28]. Although several steps have been taken to reduce the menace, cheating has not stopped as cheaters will always cheat regardless of the method [29]. Whatever means that is available, people were ready to use it. The cheaters were considered opportunists, because they elect to cheat based on the available opportunities. With this determination by cheaters, it is therefore important that a clear identification of factors and related stakeholders is undertaken so as to seal any loophole that may give an opportunity for misconduct in an examination.

Recent studies like $[28,30,31]$ have also confirmed that the major causes of examination malpractices have not really changed from the past. What may have changed is the nature of how these misconducts are committed. Other authors [32] have summed up that the locus of control and self-control [33] have some effect on the ability to cheat in an examination. Furthermore, an analysis of different studies undertaken from 2012-2019 by various researchers on the motivation for cheating in examinations [34] confirmed that the causes of cheating in examinations are still valid to date as they were previously researched. The literature has shown that the causes of examination malpractices need to be critically addressed, so that the menace can be reduced. As confirmed by [34], the identified causes in the literature reviewed agree with each other. It has also been noted from the literature that the factors that tend to influence examination malpractices are the same regardless of the level of education, whether primary, secondary, or tertiary. It is therefore important that every stakeholder in the examination management process takes up their responsibilities as observed by [35].

Despite the causes of examination malpractice not having changed over the years and efforts made to end the practice, this bad practice has continued to occur. This can be attributed to the fact that examination malpractices cannot be controlled by one party unless "the whole society adopts a degree of responsibility, integrity, and sincerity" $[20,36]$. It is for this reason that this study is breaking down the causes and relate each cause to a stakeholder, so that a comprehensive analysis of each factor can be undertaken.

Given the importance of maintaining credibility in the examination process several researchers have endeavored to find out the major causes of examination misconduct by taking a holistic approach, this study has endeavored to break down/isolate the causes/actions by each stakeholder in the examination management process so as to analyze critically and understand the root cause of misconduct. Once the root causes are clearly understood, the process of finding mitigating factors would be done in a proactive manner as opposed to being reactive when a situation occurs. Just as the process of killing a natural tree is to attack the roots, so it should be with examination malpractices. Local studies reviewed showed the main focus being on effects of examination malpractices, and those that investigated the causes did not break them down by each stakeholder in the examination management process.
2.6. Conceptual Model. The study was conceptualized using the adapted conceptual model of [37] represented in Figure 2. This model was used to aid in the investigation of some of the causes of examination malpractices. The conceptual model in Figure 2 shows how various stakeholders may engage in actions in the management of examinations, which would result in examination malpractices and leakages. The four (4) key actors in the examination process that have been considered in this study are teachers, learners, government, and parents/community. In this paper, the discussion is centered on the actions of stakeholders in the examination management process that lead to examination malpractices.

2.7. Review of the Conceptual Model. Examination management, as opined by [37], is the process of planning, organizing, and administration of examinations. It begins from the classroom where learners are taught and prepared for examinations, setting of examination questions by the examining body in the case of public examinations, marking answer scripts, grading, and finally awarding of certificates. In this process, different stakeholders are involved such as teachers, learners, the government, and parents or the community of which each one has a role to play at different stages of the examination management process in order to have a quality and secure examination management system. When these roles are violated, it leads to the mismanagement of examinations, and examination malpractices occur. Some of the wrong actions are discussed, which can lead to examination malpractices, of which some of them are acts of commission, while others are actions of omission by different stakeholders in the examination management process.

2.8. Teachers. In our adapted conceptual model, teachers have a responsibility to impart skills and knowledge to the learners, so that they can be well prepared for the assessments/examinations at the end of their course of study. The National Policy on Education, 1996, Educating Our Future, states that teachers at basic and secondary school level must be well trained to handle the levels that they teach, so as to provide quality education [38]. Despite training many teachers, the government of Zambia still faces a shortage of teachers in schools, especially in the rural areas. In certain rural schools, where only one teacher is available to teach all classes or where teachers are just insufficient, the quality of education that learners receive is compromised by the few teachers who must teach all classes. As such, even syllabus coverage is incomplete, and learners are ill prepared for examinations, or worse, still the few teachers available are not competent enough to teach in all subject areas coupled with the time constraint to handle several classes. As a result, during examinations, the teacher may resort to assisting learners, leaking examination questions to learners. Moreover if the remuneration for teachers is not adequate, they may resort to selling examination questions or getting bribes from parents as a way of complementing their poor salaries. All these factors can create an enabling environment for examination malpractices. 
Examination Management Process

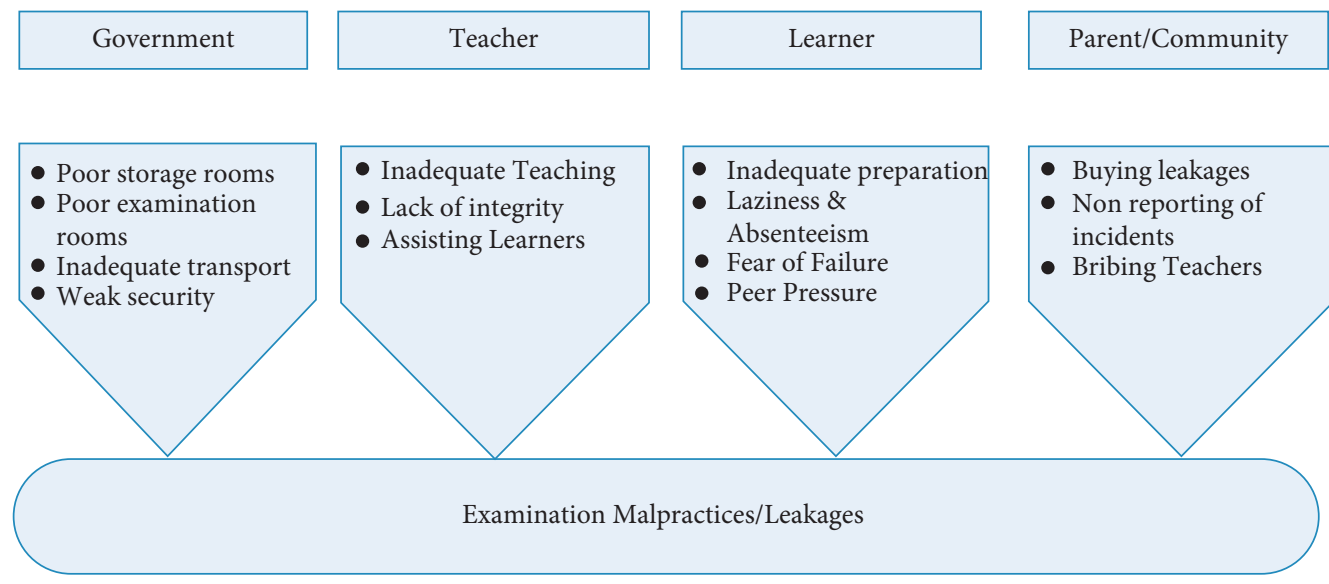

Figure 2: Adapted conceptual model.

Ogunji's model says that the teacher's incompetence, when they have not taught the pupils well, will involve themselves in leaking examination papers or aiding pupils to help them pass their examinations [37]. In other instances, they do that to make extra income because of poor remuneration.

2.9. Government. The government has a bounden duty to promote the highest standard of quality education for all [38], which entails giving attention to quality curriculum and facilities as well as the responsibility of rewarding teachers' services and sustaining their morale through satisfactory terms and conditions of service [38]. Provision of good school infrastructure and adequate funding on education is also very cardinal, as that would ensure adequate and good school facilities. Most times, the government inadvertently contributes to examination malpractices by inadequate funding to schools, poor or lack of transport for transporting examination materials, having poor infrastructure for storage of examinations, inadequate or poor classrooms for examination purposes, where learners overcrowd during examinations. Overcrowding in examination centers leads to learners copying from each other.

2.10. Parents and the Community. In the fight against examination malpractices, everyone is expected to be involved. In a statement by [39], parents and the community at large are to be part of the fight in order to preserve the integrity of the education system. If parents and the community are not vigilant, they can contribute to examination malpractices by not reporting those that they see involving themselves in such acts, not reporting people selling examination questions but instead buying examination questions for their children or wards or even giving money to children to buy leakage [36] in [20]. Other ways are where parents bribe teachers so that they aid their children as observed by [20] in their study.
2.11. Learners. In a study conducted by [17], it was revealed that laziness, absenteeism, loss of focus or lack of concentration, fear of failure, and pressure from parents that [20] also found to be what causes candidates to indulge in examination malpractices. Learners have the responsibility of preparing adequately for examinations, and when this does not happen, they engage themselves in such vices for them to pass the examination.

\section{Materials and Methods}

3.1. Study Area. The study was conducted in Zambia, located in the Southern Central region of Africa, a landlocked country with eight (8) neighboring countries around as shown in Figure 3. The area of the country is approximately $752,618 \mathrm{~km} 2$ with an estimated population of 17,351,804 in 2018 as retrieved from World Population Prospects 2019 revision (https://www.population.un.org). The country has ten (10) provinces and 116 gazette districts (as at the end of August, 2020).

3.2. Methods. This article is an extract of a broader study, which adopted a descriptive survey. A descriptive survey was found to be more appropriate for the study because we needed a description of factors that cause examination malpractices in Zambia as they existed at present. Knowing the current state of affairs was important in order for the next steps to be taken. The data reported in this article are answering to one of the research questions about the perception of teachers on stakeholder actions or factors that lead to examination malpractices in school examinations in Zambia. The study adopted a semistructured questionnaire to collect data, which was first pretested in two provinces in 16 districts. Modifications were made to the questionnaire based on the observations received from the pretesting. The questionnaire comprised both closed and open-ended 


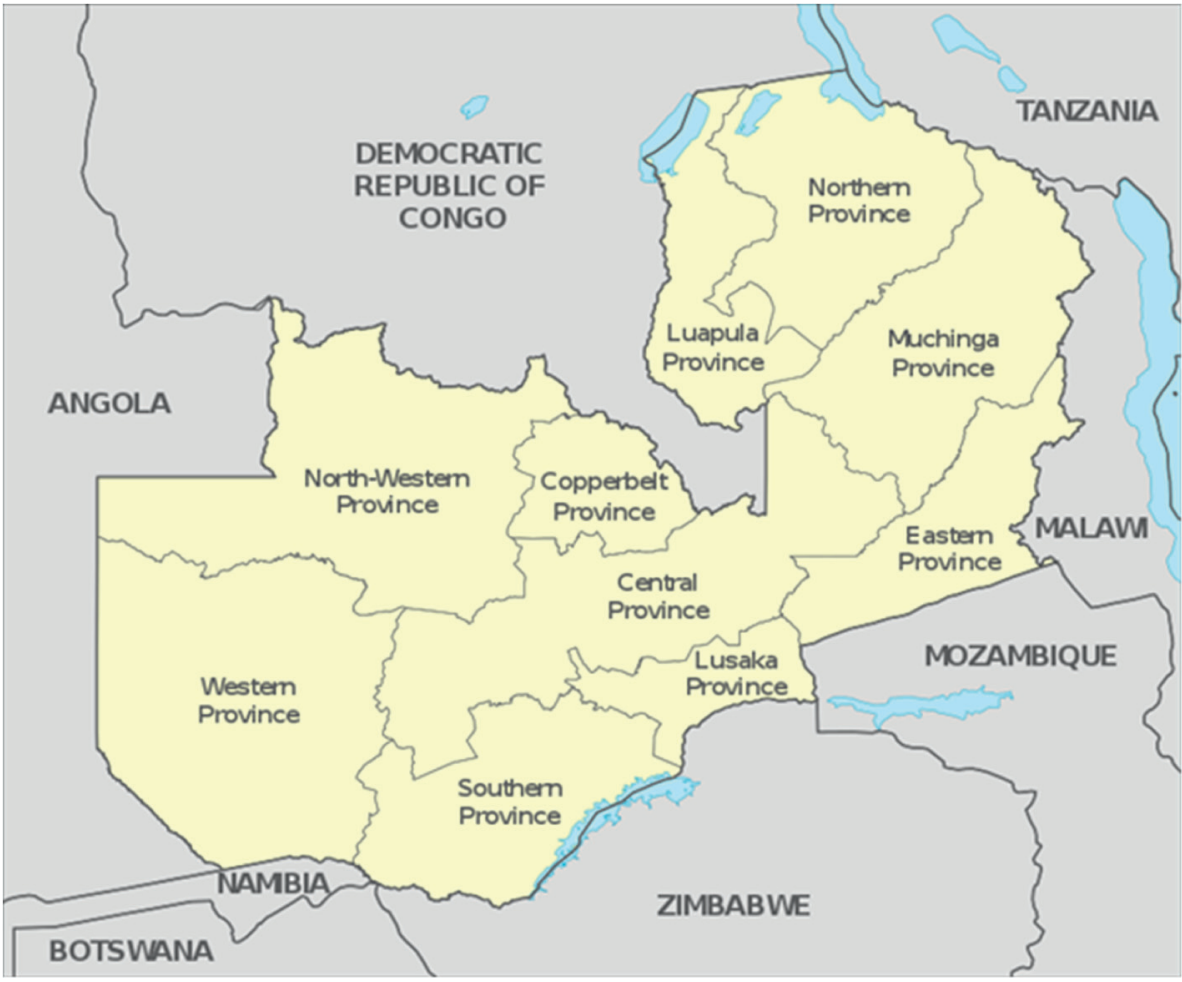

FIgURE 3: Map of Zambia with neighboring countries [40].

questions to collect data about the teachers' perception on the roles of four (4) key stakeholders identified in the examination management process.

At the time of undertaking the study, there were a total of 11,443 examination centers that conduct any one of the examinations offered by ECZ, and these are Grade 7, Grade 9 Internal, Grade 9 External, Grade 12, and GCE examinations and 115 districts [41]. All the districts were considered with three (3) participants from three (3) randomly selected examination centers. This was to ensure that there was a balance between rural and urban districts. The participants selected were School Guidance Teachers who were purposively selected because they are the ones responsible for managing examinations at a school level. These have a better understanding of the examination management process with adequate experience in matters relating to examination administration and were better placed to provide the information required on the subject of examination malpractices and the stakeholders involved.

Furthermore, School Guidance Teachers are a nexus of all four stakeholders highlighted, and they have a greater understanding of each stakeholder in their interactions with them, as illustrated in Figure 4.

The School Guidance teachers were seen to be the focal point of contact for all the four stakeholders. This is because teachers connect with learners during teaching and learning time, and they interact with parents/community during school open days and also live in the same communities. Additionally, teachers interact with the government as their employer, and they are the ones who use the facilities provided by the government. Finally, they associate with their co-workers, the teachers, while performing their jobs, as well as being aware of the actions of teachers who engage in examination malpractices. They were a good choice to give their opinion on all the stakeholders that were conceptualized in the study.

The researchers were constrained with time and resources and hence the choice of the School Guidance Teachers to give their views on the stakeholder roles and factors leading to examination malpractices. The purpose of the data being collected was clearly explained, and the participants were asked to give individual verbal consent to participate in the study. Participants were assured that all the information given would be kept confidential, used for the intended purpose only, and their identity kept anonymous as the study did not include anything that would identify them like school name. The questionnaire focusing on their views about the role of government, teachers, learners, and parents/community that lead to examination malpractices was distributed after giving consent. Open-ended questions were asked on the perception of teachers about each stakeholder factors that contribute to examination malpractices. The use of open ended questions in this regard was to freely gather more information from the participants without any limitation of predetermined answers or without preempting any answers, which would later be compared with the existing literature. This was to also solicit for new responses if any existed at the time of the study.

3.2.1. Instrument. A self-administered questionnaire was used to collect data. The questionnaire was administered to the respondents with the help of research assistants who 


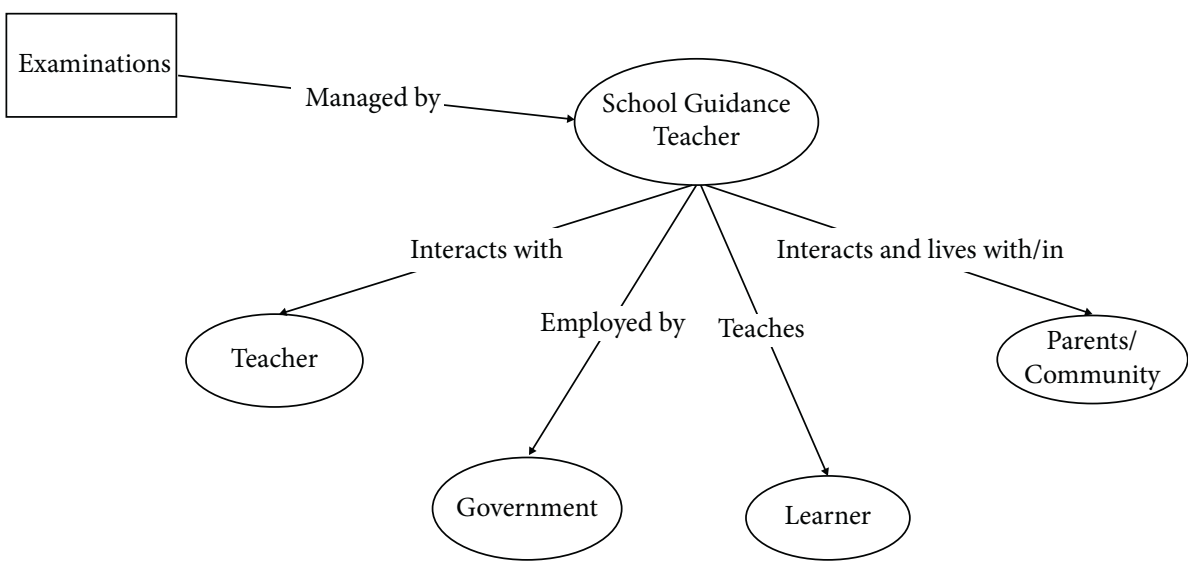

FIGURE 4: Illustration of stakeholder relationship.

visited eight (8) provinces in June/July 2019. One of the authors visited two provinces and administered the questionnaire there. The questionnaire was divided into sections, namely, the personal demographic data such as occupation, sex, type of institution, and highest level of education; prevalence of examination malpractices in the area, forms of examination malpractices, general causes of examination malpractices, and teachers' perception on each stakeholder's actions that lead to examination malpractices.

3.2.2. Data Analysis. The first step in data analysis was to examine the returns for completeness. The responses were received from 297 respondents, out of which 18 were not properly filled in and were not included in the analysis. The remaining 279 that were fully completed were used for the study. The questionnaire comprised both closed- and openended questions, which were mainly follow-up questions. Open-ended questions collect data qualitatively, which are analyzed using themes. However, due to the time constraint on the part of the researcher, open-ended questions were closed up by coming up with the common answers and coding them for easy analysis. Responses were grouped according to the stakeholder they related to. Data from the field were analyzed using IBM Statistics 23. Descriptive statistics of frequency counts and percentages tables and charts were used to present the findings of the study.

The second part of the analysis was to carry out a chisquare test, which is a nonparametric test to determine whether there were any significant differences in the views of teachers that had experienced examination malpractices in their area from those who had not. A chi-square test was the appropriate test to use because of the type of data collected, which were mainly nominal and categorical. The test was carried out for each stakeholder that is government, teacher, learner, and parent/community at a significance level of 0.05 $(p<0.05)$. This level of statistical significance is a convention that is used among most social researchers and is acceptable at $p<0.05$. This implies that there are fewer than 5 chances in 100 [42].

\section{Results and Discussion}

A brief overview of demographics of the participants in this study is presented in Table 1 . The participants comprised 275 teachers, two (2) Education Standards Officers, and two (2) others who were Statisticians from the District Education Board Secretary's (DEBS) office. Of the 279 participants, there were more males than females who are given the responsibility to manage examinations in schools, $79.9 \%$ males and $20.1 \%$ females drawn from 199 ordinary standalone centers and 76 Zonal centers, which are used as zonal schools or centers, and four (4) DEBS offices. The majority of the respondents were holders of a Diploma or higher, which means they were all well qualified in their roles and would give appropriate responses for the study.

\subsection{Analysis of Items (Examination Malpractices} Occurrences). The analysis is presented by item to respond to the main research question, which is "What role does each of the following stakeholders play that leads to examination malpractices? Government, Teachers, Learners, and Parents/ Community." One of the items of the questionnaire asked if participants had experienced examination misconduct in their school or area. This question was important because a further analysis was required to compare the views of teachers from schools that had experienced examination malpractices and those that had not. It was discovered that examination malpractices had happened in 48 percent of the participants' areas, as depicted in Figure 5, while $37.1 \%$ said they had not. A small percentage of $14.9 \%$ indicated that they were not sure. This gave a good balance of those who had experienced examination misconduct in their areas and those who had not as we were able to get views from both experience and nonexperience of examination malpractices.

4.2. Forms of Examination Malpractices. A follow-up question was asked to find out the types of examination malpractices that had occurred in the participant's area. 
TABle 1: Demographics of respondents $(N=279)$.

\begin{tabular}{|c|c|c|}
\hline Variable & No. & $\%$ \\
\hline \multicolumn{3}{|l|}{ Gender } \\
\hline Male & 223 & 79.9 \\
\hline Female & 56 & 20.1 \\
\hline \multicolumn{3}{|l|}{ Highest level of education } \\
\hline Certificate & 1 & 0.4 \\
\hline Diploma & 54 & 19.4 \\
\hline Bachelor's degree & 201 & 72.0 \\
\hline Master's degree & 23 & 8.2 \\
\hline \multicolumn{3}{|l|}{ Occupation of respondents } \\
\hline Teacher & 275 & 98.6 \\
\hline Education standards officer & 2 & 0.7 \\
\hline Others & 2 & 0.7 \\
\hline \multicolumn{3}{|l|}{ Category of institution } \\
\hline Ordinary school & 199 & 71.3 \\
\hline Zonal school & 76 & 27.2 \\
\hline DEBS office & 4 & 1.4 \\
\hline
\end{tabular}

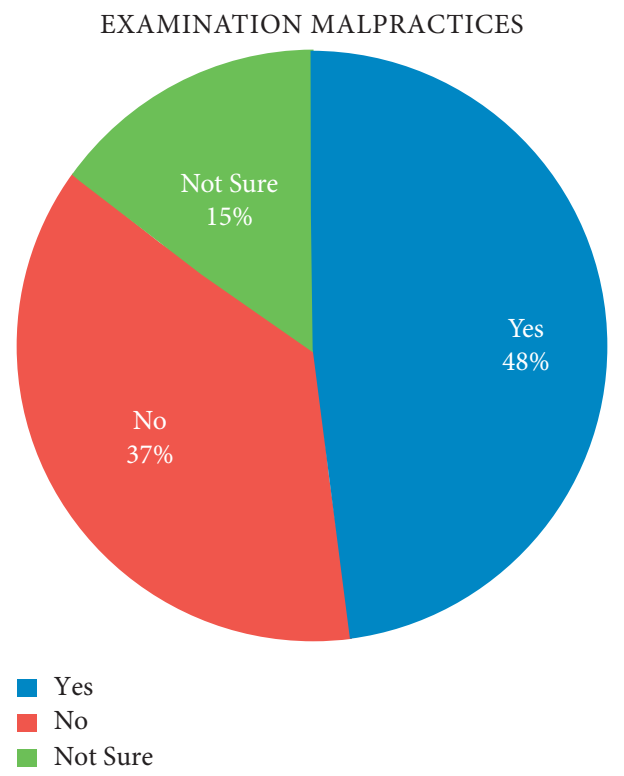

Figure 5: Occurrence of examination malpractices.

Participants indicated the different forms of examination malpractices that they had experienced. Figure 6 shows prior knowledge/leakage at $43.3 \%(N=58)$ as the most prevalent form of examination malpractice followed by smuggling of unauthorized materials into the examination room at $37.3 \%$ $(N=50)$. Other forms indicated were candidates copying from each other at $6.7 \%(N=9)$, assistance at $10.4 \%(N=14)$, and collusion at $0.7 \%(N=2)$. The findings of this study corroborate those of other studies $[19,20]$, who discovered similar forms of examination misconduct. Similar forms of misconduct were also observed before in Nigeria by [16] as part of the study on causes and effects of examination malpractices on national development.

A few participants who had not experienced examination malpractices also mentioned some common malpractices that they know. These forms give an indication of which stakeholders are mainly involved. For example, leakages can involve all four (4) stakeholders, Teachers, Government, Learners, and community/parents as indicated in our conceptual model. Poor infrastructure, and weak security that can easily expose the examination question papers relate to government. Community once they have access can make it a business venture by selling these question papers. Assistance can be attributed to teachers and learners, and smuggling prewritten notes, copying, and collusion are also learner related.

4.3. Causes of Examination Malpractices. Before breaking down the causes of examination malpractices to each stakeholder, a question on the reasons of examination malpractices was posed to obtain a general view of the phenomenon. The findings on the causes of examination malpractices and leakages are summarized and ranked as presented in Table 2. The findings are further represented in 


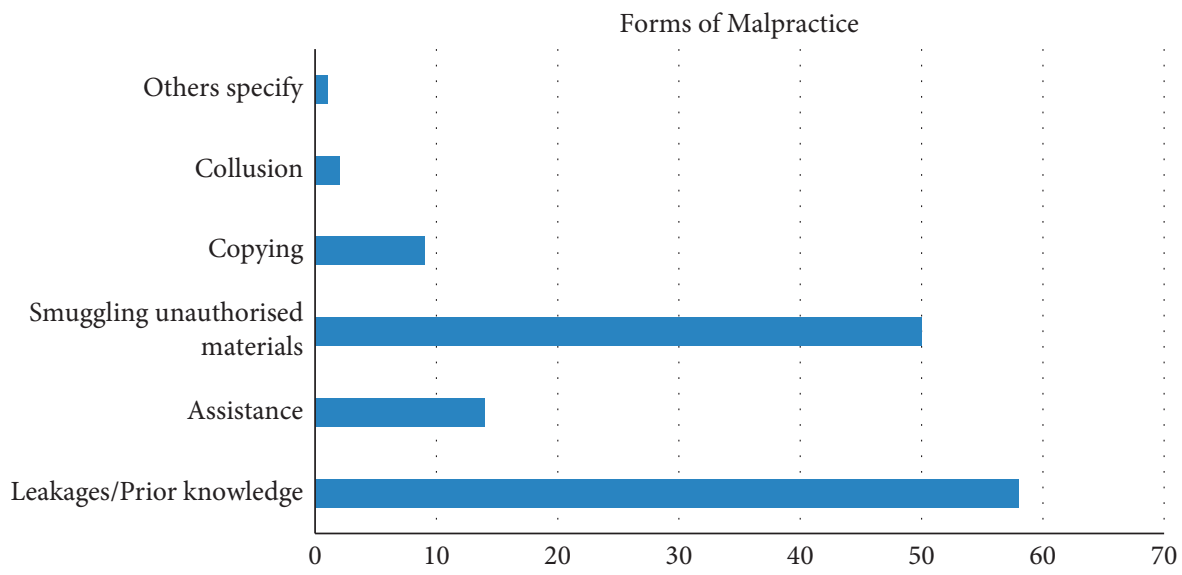

FIGURE 6: Forms of the examination malpractice.

TABle 2: Causes of examination malpractices.

\begin{tabular}{|c|c|c|c|c|}
\hline No. & Cause & Frequency & Percent & Rank \\
\hline 1 & Lack of preparedness by learners & 73 & 26.2 & $1^{\text {st }}$ \\
\hline 2 & Desire for money & 24 & 8.6 & $5^{\text {th }}$ \\
\hline 3 & Lack of adequate teaching & 46 & 16.5 & $2^{\text {nd }}$ \\
\hline 4 & Easy dissemination of papers through electronic/social media & 7 & 2.5 & $10^{\text {th }}$ \\
\hline 5 & Schools want to maintain status with high pass rates & 9 & 3.2 & $9^{\text {th }}$ \\
\hline 6 & Poor security during delivery and poor storage facilities & 26 & 9.3 & $4^{\text {th }}$ \\
\hline 7 & Lack of integrity by those handling examinations & 19 & 6.8 & $7^{\text {th }}$ \\
\hline 8 & Long duration of examinations & 6 & 2.2 & $11^{\text {th }}$ \\
\hline 9 & Weak security network & 33 & 11.8 & $3^{\text {rd }}$ \\
\hline 10 & Pressure from the parents/community & 20 & 7.2 & $6^{\text {th }}$ \\
\hline \multirow[t]{2}{*}{11} & Teachers not completing the syllabus & 16 & 5.7 & $8^{\text {th }}$ \\
\hline & Total & 279 & 100.0 & \\
\hline
\end{tabular}

Tables 3-5 and 6 segregated by each stakeholder as perceived by teachers from areas that had experienced examination malpractices and those that had not.

The several causes of examination malpractices and leakages as identified from the questionnaires in Table 2 show that the top six causes on the list were lack of preparedness by learners $\left(1^{\text {st }}\right)$ giving a $26.2 \%$, lack of adequate teaching $\left(2^{\text {nd }}\right)$ at $16.5 \%$, weak security $\left(3^{\text {rd }}\right)$ at $11.8 \%$, poor security during delivery and poor storage facilities $\left(4^{\text {th }}\right)$ giving $9.3 \%$, and desire for money $\left(5^{\text {th }}\right)$ at $8.6 \%$. Other factors shown in Table 2 include pressure from parents and community (7.2\%), lack of integrity by those who handle examinations (6.8\%), and teachers not completing the syllabus (5.7\%). These findings constitute the major causes of examination malpractices in Zambia. Other causes mentioned are schools wanting to maintain their status with high pass rates $(3.2 \%)$, easy dissemination of papers through electronic/social media $(2.5 \%)$, and long duration of examinations (2.2\%).

Lack of preparedness by learners is topping the list showing that learners are a major stakeholder in the process and have a bigger role to play if examination malpractices were to be reduced. The second aspect in the ranking is inadequate teaching, which relates to a teacher's capacity to teach effectively and complete the curriculum on time. Furthermore, the third and fourth factors refer to government infrastructure provision, including security of examinations in transit, storage, and during examinations. The last two factors on the top six list are linked to parents who want more money as well as putting pressure on their children to pass the examination. When learners prepare adequately for examinations, then they can withstand pressure from parents and the community, because they would have no need of engaging themselves in examination misconduct. Similarly, when teachers provide adequate instruction, they will not consider examination misconduct in any way. These findings agree with [43] who also found similar top five causes if the causes of examination malpractice were to be arranged in the order of importance. The findings suggest learners as the major contributor, followed by Teachers, then government, and the lowest being Parents/ community.

A further question was to get the views of teachers on the roles each stakeholder plays that lead to examination malpractices. Factors were identified according to each stakeholder as viewed by participants and are presented in the sections that follow.

4.4. Teacher Related Factors. Teacher factors that lead to examination malpractices were investigated and presented in Table 3 as perceived by participants. The participants' perceptions of teacher-related factors are also divided into 
TABLE 3: Teacher related.

\begin{tabular}{|c|c|c|c|c|c|}
\hline \multirow{2}{*}{ Factors } & \multicolumn{3}{|c|}{ Examination malpractice? } & \multirow{2}{*}{ Frequency } & \multirow{2}{*}{ Percent } \\
\hline & Yes & No & Not sure & & \\
\hline Poverty & 10 & 5 & 0 & 15 & 5.4 \\
\hline Desire for more money & 15 & 8 & 3 & 26 & 9.3 \\
\hline Lack of integrity and morals & 20 & 14 & 8 & 42 & 15.1 \\
\hline Inadequate teaching and noncompletion of syllabus & 72 & 54 & 24 & 150 & 53.8 \\
\hline Desire to maintain high pass rates in their school & 17 & 15 & 2 & 34 & 12.2 \\
\hline Assisting learners & 4 & 6 & 2 & 12 & 4.3 \\
\hline Total & 138 & 102 & 39 & 279 & 100.0 \\
\hline
\end{tabular}

Source: Field Data, 2019.

TABLE 4: Learner factors.

\begin{tabular}{|c|c|c|c|c|c|}
\hline \multirow{2}{*}{ Factors } & \multicolumn{3}{|c|}{ Examination malpractice? } & \multirow{2}{*}{ Frequency } & \multirow{2}{*}{ Percent } \\
\hline & Yes & No & Not sure & & \\
\hline Lack of preparation for examinations & 46 & 32 & 14 & 92 & 33.0 \\
\hline Secure a place at the next level & 15 & 6 & 3 & 24 & 8.6 \\
\hline Fear of failure & 22 & 11 & 6 & 39 & 14.0 \\
\hline Laziness and absenteeism & 31 & 12 & 5 & 48 & 17.2 \\
\hline Peer pressure & 8 & 10 & 4 & 22 & 7.9 \\
\hline Pressure from school/competition & 4 & 5 & 1 & 10 & 3.6 \\
\hline Lack of self confidence & 8 & 19 & 4 & 31 & 11.1 \\
\hline Pressure from parents/community & 4 & 7 & 2 & 13 & 4.7 \\
\hline Total & 138 & 102 & 39 & 279 & 100.0 \\
\hline
\end{tabular}

TABLE 5: Community/parent related factors.

\begin{tabular}{|c|c|c|c|c|c|}
\hline Factor & Yes & No & Not sure & Frequency & Percent \\
\hline Not monitoring learners school progress & 77 & 51 & 24 & 152 & 54.5 \\
\hline Business venture & 5 & 9 & 0 & 14 & 5.0 \\
\hline Nonreporting of malpractices & 33 & 22 & 6 & 61 & 21.9 \\
\hline Bribing teachers & 11 & 10 & 5 & 26 & 9.3 \\
\hline Buying leakages & 12 & 10 & 4 & 26 & 9.3 \\
\hline Total & 138 & 102 & 39 & 279 & 100.0 \\
\hline
\end{tabular}

Source: Field Data - 2019.

TABLE 6: Government related factors.

\begin{tabular}{|c|c|c|c|c|c|}
\hline \multirow{2}{*}{ Government related factors } & \multicolumn{3}{|c|}{ Examination malpractice? } & \multirow{2}{*}{ Frequency } & \multirow{2}{*}{ Percent } \\
\hline & Yes & No & Not sure & & \\
\hline Poor security during delivery & 19 & 10 & 5 & 34 & 12.2 \\
\hline Poor storage facilities & 22 & 21 & 9 & 52 & 18.6 \\
\hline Inadequate transportation vehicles & 20 & 19 & 1 & 40 & 14.3 \\
\hline Poor teaching and learning environment & 8 & 4 & 3 & 15 & 5.4 \\
\hline Weak security & 38 & 31 & 14 & 83 & 29.7 \\
\hline Punishment not severe enough to deter offenders & 5 & 3 & 1 & 9 & 3.2 \\
\hline Inadequate examination rooms & 2 & 4 & 1 & 7 & 2.5 \\
\hline Poor remuneration for teachers & 24 & 10 & 5 & 39 & 14.0 \\
\hline Total & 138 & 102 & 39 & 279 & 100.0 \\
\hline
\end{tabular}

Source: Field Data 2019.

those who had experienced examination misconduct in their areas, those who had not, and those who said they were unsure. Table 3 shows inadequate teaching (53.8\%) leading to noncompletion of the syllabus as one of the major factors resulting in examination misconduct. This finding is commensurate to the findings of [20] who also ranked this as a major contributor to examination malpractices as well as the findings of $[28,44,45]$. The second factor perceived next to inadequate teaching is lack of integrity and morals (15.1\%), followed by schools wanting to maintain high pass 
rates $(12.2 \%)$, so that the school can have a good name in terms of high passing rates. This may be to attract prospective learners to a particular school. However, another factor mentioned is more to do with teacher selfishness where they desire for more money $(9.4 \%)$, which resonates well with [46]'s finding that the quest for money by lecturers contributed to examination misconduct. The last two factors, poverty (5.4\%) and assisting candidates (4.3\%), ranked lowest in this study despite having been among the causes mentioned by other researchers $[19,25]$. This, however, does not mean that these factors are insignificant and should be ignored; they still need attention so as to mitigate their effects on the examination process.

4.5. Learners Related Factors. The analysis on learner related factors shown in Table 4 revealed that lack of preparedness for the examination (33\%) turns out to be the major contributing factor that leads to learners engaging in examination misconduct, followed by laziness and absenteeism $(17.2 \%)$, which tends to tie well with lack of preparedness. These findings agree very well with the findings of other researchers such as $[20,43,46,47]$, and it appears that this problem has been persistent for a long time based on what other previous researches found. In some cases, learners engage in examination misconduct not that they are not intelligent, but even intelligent ones find themselves in misconduct, because they lack self-confidence as mentioned in the findings of this study. They tend to doubt their ability to recall in the examination room what they have learnt. On the other hand, [48] found that learners questioned a lack of confidence as a reason for engaging in malpractices, although teachers saw it as a cause, which is consistent with the findings of this study. Other factors such as fear of failure $(14 \%)$, wanting to secure a place at the next level of education $(8.6 \%)$, and peer pressure $(7.9 \%)$ have also been viewed as learner factors that tend to contribute to examination malpractices. Pressure from school and competition (3.6\%) is another factor mentioned here. Parents also put pressure on learners to pass their examination, who in trying to impress their parents with good grades end up involving themselves in examination misconduct. In agreeing with parental influence, the author [20] indicated that "parents consider cheating the right of their children and make approaches to the supervisory staff at any cost."

4.6. Community/Parents Related Factors. The analysis of the results on parent/community related factors presented in Table 5 revealed that, for most of the participants in this study, not monitoring learners' school progress by parents during learning and examination time (54\%) is a major contributor to examination malpractices for this stakeholder. Parental guidance is critical in a child's education since it prevents the learner from going off on their own. Another factor that stands out from the study is that the community is not actively involved in fighting examination malpractices, such that they do not report examination malpractices or suspected malpractices $(21.9 \%)$ that happen in their communities. On the other hand, the results revealed that parents and members of the community offer bribes to teachers (9.3\%) and buy leaked examination questions (9.3\%) for their children/wards. Another interesting finding is that some members of the community have made it a business venture (5\%) by selling leaked examination questions. All these actions relating to community/parents were viewed as contributing to the menace and agree with what [39] said and researchers like [20, 45] also found out that parental or community involvement in learner's education plays a pivotal role.

4.7. Government Related Factors. The findings presented in Table 6 show the views of participants on how government unwittingly contributes to examination malpractices by not having adequate infrastructure for examination purposes, teaching and learning such as weak security system $(29.7 \%)$ inadequate examination rooms $(2.5 \%)$, poor teaching and learning environment (5.4\%), inadequate transportation vehicles for examinations $(14.3 \%)$, poor or insecure storage facilities for examinations (18.6\%), and poor security during delivery of examinations $(12.2 \%)$. The provision of adequate teaching and learning materials as well as good and adequate infrastructure to support the education sector is the duty of the government of the Republic of Zambia as indicated in [38]. Neglecting this duty inadvertently leads to examination misconduct, because when good facilities are not available, other stakeholders will have easy ways of engaging in examination misconducts. For example, overcrowding in the examination room, which [45] also alluded to, will encourage learners to copying from each other or colluding; poor storage facilities and weak security make easy access to the examination papers.

Besides factors relating to infrastructure found out in the study, participants also cited poor remuneration for teachers $(14.0 \%)$ and punishment not severe enough to deter offenders (3.2\%) as the lowest percentage. From these results, it is clear that the factors relating to government mainly hinge on infrastructure followed by remuneration of teachers and lastly the weak legislation. Other studies have found weak legislation and nonimplementation of it [20, 25] to have contributed heavily to the scourge, because offenders were not afraid of the punishment, which was seen as not punitive enough.

4.8. Chi-Square Test of Independence. The chi-square test was used to examine if there was any statistically significant difference between the perception of teachers from areas that had experienced examination malpractices and those from areas that had not on each stakeholder's actions leading to examination malpractices. The results of the chisquare test presented in Table 7 show no significance difference observed between the two groups of teachers for stakeholders Government, Teachers, and Community except the Learner stakeholder suggesting that both groups possess similar views. This could indicate that learners are getting more sophisticated with the emergence of technology in cheating, and those with experience tend to have a better understanding of learner behavior. With 
TABLE 7: Chi-square test.

\begin{tabular}{lccc}
\hline Chi-square test & Pearson chi-square statistic $\left(\mathrm{X}^{2}\right)$ & df & Sig. \\
\hline Teacher & 8.469 & 10 & 0.583 \\
Learner & 21.937 & 12 & 0.038 \\
Community/parent & 8.820 & 8 & 0.358 \\
Government & 10.211 & 12 & 0.597 \\
\hline
\end{tabular}

Source: Field Data 2019.

the current dynamics of cheating in an examination, those who had not experienced it may not be very familiar with the current trends.

\section{Conclusions and Recommendations}

This study investigated the perception of teachers on how the four key players in the examination management process contribute to examination malpractices and leakages. The four key players identified are Teachers, Learners, Government, and Parents/Community. How each of these stakeholders contributes to malpractices was identified in the study.

The dominant or major factor pertaining to each stakeholder was noted, whereby for the learner, it was inadequate preparation for the examination, while the major teacher factor that came out of the study was inadequate teaching and failure to complete the syllabus. Poor and inadequate infrastructure was attributed to government as a major lead to examination misconduct, while lack of monitoring learner's school progress was a major factor for the Parent/Community Stakeholder. A vigilant community is therefore required to end the scourge.

Based on the results and the factors identified, the study recommends the mitigation of negative actions found on each stakeholder, so that there is a reduction in the examination misconduct. Learners should work hard in school and reduce on absenteeism; parents should monitor their children and encourage them to work hard; teachers should teach adequately; and government should improve school infrastructure so as to provide a conducive environment for learning, teaching and assessment.

The results also indicate leakages/prior knowledge of the examination questions having the highest percentage. As such, a further recommendation in abating factors related to government is the use of current technologies to secure examination materials. By implementing an examination management system based on Internet of Things (IoT), the unnecessary human intervention will be eliminated and ensure that the manual processes are automated. Utilization of technologies such as Radio-frequency identification (RFID) to tag the question papers and answer scripts, so that they are monitored and tracked. Use of cloud technology as well with Raspberry Pi as a central server monitoring the information. We also recommend the use of GPS trackers on transportation vehicles to enable location monitoring in transit, while, in storage places, there should be a surveillance system used to be able to detect intruders. Examination question papers and containers should be tagged with RFID tags for ease of tracking, and containers should have electronic locks with double authentication before they can be opened at designated places. This recommendation forms a basis for further works being undertaken in securing examination materials.

Further works can be undertaken to interrogate this subject of stakeholders' actions by getting views from each of the stakeholders identified as opposed to using one group, the teacher, as is the case in this study.

However, it is clear that the factors found in this study that lead to examination misconduct are still valid as earlier researched. What has changed really are the dynamics of how this felony is committed. Tackling the causes by each stakeholder gives a clear understanding of what leads to misconduct and once this has been understood, finding long lasting solutions becomes easy and systematic.

Each stakeholder identified in the study has a big role to play in the whole examination management process and as already alluded to, all stakeholders are to take part in order to end the scourge.

\section{Data Availability}

The data used to support the findings of this study are included within the article.

\section{Additional Points}

Limitations of the study. The study on how each of the identified stakeholders influences examination malpractices focused on teachers' perceptions as the point of contact with government, learners, and the community/parents. It would have been more ideal to carry out surveys with each of the four stakeholders identified, but this was not possible due to limited resources and time constraints. This study relied on the perception of teachers only.

\section{Conflicts of Interest}

The corresponding author is an employee of the examining body in Zambia.

\section{References}

[1] M. J. Kelly, Education in a Declining Economy, World Bank, Washington, DC, USA, 1991.

[2] Government of the Republic of Zambia, The Laws of Zambia-Examinations Council of Zambia Act, Government of the Republic of Zambia, Lusaka, Zambia, 1983.

[3] Examinations Council of Zambia, 2016 Examinations General Performance, Examinations Council of Zambia, Lusaka, Zambia, 2017.

[4] Examinations Council of Zambia, 2014 Examinations Performance Review Report-General Performance Analysis, Examinations Council of Zambia, Lusaka, Zambia, 2015.

[5] Examinations Council of Zambia, Examinations Council of Zambia Performance Review 2013, Examinations Council of Zambia, Lusaka, Zambia, 2014.

[6] Zambia Daily Nation, Stolen Exam Papers Shock NGO, Zambia Daily Nation, Lusaka, Zambia, 2016, https://web. facebook.com/dailynationews/posts/stolen-exam-papers-shockngo/894002080729778/?_rdc=1\&_rdr. 
[7] Z. Watchdog, Police Pick up 22 Pupils, a Teacher and Guards for Stealing Exam Papers, Zambian Watchdog, Lusaka, Zambia, 2012, https://www.zambiawatchdog.com/police-pick-up-22pupils-a-teacher-and-guards-for-stealing-g7-exam-papers/.

[8] D. Mwendabai, "4 pupils, guard arrested," Zambia Daily Mail, vol. 22, no. 286, p. 1, 2018.

[9] Government of Zambia, Constitution of Zambia (Amendment) No. 2 of 2016, Government of Zambia, Lusaka, Zambia, 2016.

[10] Lexico, "Examination," Oxford English and Spanish Dictionary, Synonyms, and Spanish to English Translator, https:// www.lexico.com/definition/examination.

[11] Collins COBUILD, "malpractice," "COBUILD advanced English dictionary," HarperCollins Publishers, New York, NY, USA, 2021, https://www.collinsdictionary.com/dictionary/ english/malpractice.

[12] O. P. Kolawole and A. Tayo, "A panoramic discourse on examination malpractices in Nigeria," Afro Asian Journal of Social Sciences, vol. 10, no. 3, pp. 1-20, 2019.

[13] B. A. Salami, "Examination malpractice and the integrity of educational credentials," in Proceedings of the 12th Annual Conference of the Association for Educational Assessment in Africa (AEAA), Accra, Ghana, September 1994.

[14] M. Shoneka, "Promoting the ethics and integrity of WAEC examinations," in Promoting Examination Ethics: The Challenge of a Collective Responsibility, pp. 66-76, Exam Ethics Project Publication, Lagos, Nigeria, 1996.

[15] J. N. Hang'andu, Legal Challenges of Examination Malpractices in Basic and Secondary Schools in Zambia, University of Zambia, Lusaka, Zambia, 2005.

[16] C. O. Onyibe, U. U. Uma, and E. Ibina, "Examination malpractice in Nigeria: causes and effects on national development," Journal of Education and Practice, vol. 6, no. 26, pp. 12-17, 2015.

[17] W. Phiri and J. Nakamba, "The effect of examination malpractices (leakages) on pupils' academic performance in geography in selected secondary schools of Kitwe district, Copperbelt province, Zambia," International Journal of Multidisciplinary Research and Development, vol. 2, no. 12, pp. 324-331, 2015.

[18] B. Ogunkola, Curtailing Malpractice in Public Examinations: A Higher Continuous Assessment Score, 2011, http://naere.org. ng/journal/curtailing_malpractice_public_examinations_con tinuous_assessment.pdf.

[19] B. Ngohi and Na'omin Adamu, Forms, Causes and Effects of Examination Malpractice on Senior Secondary School Students in Borno State, Nigeria, https:/www.academia.edu/25799113/ Forms_Causes_and_Effects_of_Examination_Malpractice.

[20] Q. Suleman, R. Gul, S. Ambrin, and F. Kamran, "Factors contributing to examination malpractices at secondary school level in Kohat division, Pakistan," Journal of Education and Learning (EduLearn), vol. 9, no. 2, pp. 165-182, 2015.

[21] M. Kaiiali, A. Ozkaya, H. Altun, H. Haddad, and M. Alier, "Designing a secure exam management system (SEMS) for M-learning environments," IEEE Transactions on Learning Technologies, vol. 9, no. 3, pp. 258-271, 2016.

[22] C. Agwu and E. Chidi, "Effects of harassment on secondary school children in some selected schools in Benin state Nigeria," Journal of Development and Sustainability, vol. 2, no. 1, pp. 13-56, 2003.

[23] S. A. Wowra, "Moral identities, social anxiety, and academic dishonesty among American college students," Ethics \& Behavior, vol. 17, no. 3, pp. 303-321, 2007.
[24] T. I. Muhammad, Analysis of the Management of Examination Malpractices in Colleges of Education in North-West Geo-Political Zone, Nigeria, Ahmadu Bello University, Zaria, PhD thesis, 2015, https://kubanni.abu.edu.ng/jspui/ bitstream/123456789/8725/1/Tanimu\%20I.\%20M.\%20Thes is\%20Title\%20Page.pdf.

[25] T. O. Adeyemi, "Examination malpractices among secondary schools students in Ondo state, Nigeria: perceived causes and possible solutions," American-Eurasian Journal of Scientific Research, vol. 5, no. 1, pp. 67-75, 2010.

[26] S. M. Rabi, L. R. Patton, N. Fjortoft, and D. P. Zgarrick, "Characteristics, prevalence, attitudes, and perceptions of academic dishonesty among pharmacy students," American Journal of Pharmaceutical Education, vol. 70, no. 4, pp. 73-78, 2006.

[27] M. V. DiVall and L. S. Schlesselman, "Academic dishonesty: whose fault is it anyway?" American Journal of Pharmaceutical Education, vol. 80, no. 3, pp. 1-2, 2016.

[28] D. Arhin, "Perceived factors influencing examination malpractices in BECE among pupils in asante Akim north district," International Journal of Innovative Science and Research Technology, vol. 5, no. 6, pp. 16-21, 2020.

[29] M. Witherspoon, N. Maldonado, and C. H. Lacey, "Undergraduates and academic dishonesty," International Journal of Business and Social Science, vol. 3, no. 1, pp. 76-86, 2012.

[30] C. C. Hapompwe, C. Kukano, J. Siwale, and M. B. Sianga, "Selected primary schools' compliance in prevention of examination malpractices in national examinations in Solwezi district, Zambia," International Journal of Scientific and Research Publications, vol. 10, no. 6, pp. 397-402, 2020.

[31] O. Kyokusingura, "Factors associated with examination malpractices in public universities: (a case study of undergraduates at the school of statistics and planning at makerere university)," Bsc. thesis, Makerere University, Kampala, Uganda, 2019.

[32] D. A. Woche and C. K. Wawire, "Relationship between self-control and examination malpractices among selected sescondary school students in Garissa county, Kenya," International Journal of Innovative Research and Advanced Studies (IJIRAS), vol. 7, no. 6, pp. 245-251, 2020.

[33] O. M. Anyanwu, "Locus of control and fresher undergraduates' participation tendency in examination malpractices in public universities in Ekiti state," International Journal of Educational Research and Policy Making, vol. 3, no. 1, pp. 353-360, 2020.

[34] D. Arhin and K. Kwakye, "A meta-analysis on perceived factors influencing examination malpractices," International Journal of Creative Research Thoughts (IJCRT), vol. 8, no. 6, pp. 1086-1092, 2020.

[35] F. A. Adeniran, K. M. Bakare, and O. A. Akinpade, "The stakeholders' responsibilities in managing examination malpractice in secondary schools, in Lagos state, Nigeria," International Journal of Advanced Academic Research, vol. 6, no. 4, pp. 13-36, 2020.

[36] I. Ajayi, Examination Cheats, Newswatch Magazine, Lagos, Nigeria, 2009.

[37] J. A. Ogunji, "Examination management and examination malpractice: the nexus," Journal of International Education Research (JIER), vol. 7, no. 4, pp. 53-64, 2011.

[38] Ministry of Education, Educating Our Future, National Policy on Education, Zambia Educational Publishing House, Lusaka, Zambia, 1996.

[39] M. M. Chilala, Interviewee, Education Reforms Press Briefing, Lusaka, Zambia, 2019. 
[40] Wikipedia, "Zambia administrative divisions, wikimedia," https://upload.wikimedia.org/wikipedia/commons/3/3c/ Zambia\%2C_administrative_divisions_-_en_-monochrome.svg.

[41] Examinations Council of Zambia, 2019 Examinations Results Highlights, Examinations Council of Zambia, Lusaka, Zambia, 2019.

[42] A. Bryman, Social Research Methods, Oxford University Press, Oxford, UK, 5th edition, 2016.

[43] O. P. Kolawole, "The causes and effects of examination malpractices on educational standard (a case study of selected secondary schools in oyun local goverment area of Kwara state)," International Journal of Social, Politics \& Humanities, vol. 3, no. 1, pp. 51-72, 2019.

[44] S. I. Akaranga and J. J. Ongong, "The phenomenon of examination malpractice: an example of nairobi and kenyatta universities," Journal of Education and Practice, vol. 4, no. 18, pp. 87-96, 2013.

[45] F. O. Orji, B. C. Madu, and N. A. Nwachukwu: Causes and Effects of Examination Malpractices on the Performance of Secondary School Students in Orumba South L. G. A., Anambra State, 2016, https://www.academia.edu/16562467/ Causes_and_Effects_of_Examination_Malpractices_on_the_ Performance_of_Secondary_School_Students_in_Orumba_ South_L_G_A_Anambra_State.

[46] E. C. Amadi and A. R. Opuiyo, "Forms and causes of examination malpractice among university students: a case of rivers state university, Port Harcourt," International Journal of Innovative Education Research, vol. 6, no. 1, pp. 37-41, 2018.

[47] M. M. Chianson and E. E. Otor, "Degradation in the standard of teaching and learning due to examination malpractice," Journal of Research and Methods in Education, vol. 3, no. 2, pp. 61-63, 2013.

[48] R. Nambela, "An investigation on the forms and causes of examination malpractices in Zambia: a case study in the selected schools in Lusaka district," Bachelor of Education Thesis, Cavendish University, Lusaka, 2020. 